\title{
Social Identity Theory
}

\author{
Daan Scheepers \\ Leiden University / Utrecht University, the Netherlands
}

Naomi Ellemers

Utrecht University, the Netherlands

Chapter to appear in K. Sassenberg and M. L. W. Vliek (Eds.), Social psychology in action: Evidence-based interventions from theory to practice. 


\begin{abstract}
According to social identity theory people derive part of their identity — their social identity — from the groups to which they belong (e.g., an identity as "student", "woman", "left-hander", or "Barcelona supporter"). Social identities differ in strength and content. The strength component is conceptualized in terms of social identification (e.g., "I identity strongly with Europeans"), while the content of social identity is determined by the group's features (e.g., colors associated with a soccer team) and norms (e.g., "real men don’t cry"). Social identity determines emotions (e.g., depression after a team loss) and behavior (e.g., discrimination against out-groups, or effort on behalf of one's in-group). In this chapter we outline the basic features of social identity theory - from social categorization to coping with a negative social identity — and then discuss two important domains of application: health and organizations. We conclude by describing a social identity based intervention for improving inter-group relations in an educational setting.
\end{abstract}




\section{The Groups in You}

Think for a moment about the different groups you belong to. Which groups come to mind? Maybe a sports-team, your gender, the community in which you grew-up, a group of study-friends, an online community where you play games, or the political party you voted for during the last elections. Or maybe you even think about a very abstract category, like lefthanders. When reflecting on these groups, what do you think about? And what do you feel?

When reflecting on the groups you belong to, you likely discover that you are not only a part of these groups, but that these groups are also a part of you. That is, group-membership (partly) defines your identity: Groups tell us who we are (and who we are not). Relatedly, groups also partly determine our feelings. We can have a mild, warm feeling when thinking about our fellow group members, but can also feel anger when our group is mistreated, or guilt when in-group members mistreat others.

The thoughts and feelings that arise when you think about the groups you belong to form your "social identity". More precisely defined, social identity is "that part of an individual's self-concept which derives from knowledge of membership in a social group (or groups) together with the value or emotional significance attached to that membership" (Tajfel, 1978, p. 63).

\section{Box 1. Definition Box: Social Identity}

"That part of an individual's self-concept which derives from his knowledge of his membership in a social group (or groups) together with the value or emotional significance attached to that membership" (Tajfel, 1978, p. 63)

The current chapter provides an overview of the main theoretical perspective on social identity, namely social identity theory (SIT; Tajfel \& Turner, 1979). Social identity theory is a rich theoretical perspective integrating group psychology with psychology about the self. The 
theory also has substantial practical value, and has been used to analyze important issues in organizations and society at large and to design interventions. In the current chapter we focus in particular on applications in the context of health and organizational psychology. We conclude by describing a social identity-based intervention for improving inter-group relations in an educational setting. Before describing these fields of application in more detail, in the next section we first outline the principles of SIT.

\section{The Principles of Social Identity Theory}

Social identity theory roughly consists of two parts. The first, more basic psychological part, describes the cognitive processes underlying social identity definition, and the motivational assumption that people strive for a positive social identity. The second, socio-structural part describes how people cope with a negative social identity. Before discussing these two parts we first provide a short historical background, by describing the "minimal group experiments" that stimulated the development of SIT.

\section{Groups, Just in Their Minds}

In the early 1970s, Henri Tajfel, a cognitive psychologist at the University of Bristol, England, who would become the founding-father of SIT, conducted research on the minimal criteria for group formation, and the minimal conditions for in-group favoritism to occur. To this end he designed a clever experimental setup where groups were stripped-down to their basic cognitive essence. Students who participated in the experiments were allocated to one of two groups, ostensibly on the basis of their preference for either the painter "Klee" or "Kandinsky". This was actually the only information that participants had: That there were two groups, and they were a member of one of them. There was no interaction within or between the groups; the groups thus only existed in the participants' minds, and in that sense they were truly "minimal". After being assigned to one of the groups, participants allocated 
small amounts of money between anonymous members of the "Klee" and "Kandinsky" group (excluding themselves). The results of these resource allocations indicated that participants favored people of their own group above those who had been assigned to the other group (Tajfel, 1970).

\section{Box 2. Definition Box: Minimal group}

Membership of a minimal group is based on a relatively arbitrary criterion, like being an "overestimater" or an "underestimator" on an estimation task, or simply resulting from a flip of a coin (Heads: "group A"; Tails: "Group B”). Moreover, in the classic minimal group paradigm group members are anonymous and there is no interaction within or between the groups. As a result, minimal groups are purely cognitive, i.e., the only exist in the minds of the group members. This means that minimal groups are socially meaningless outside the direct experimental context: they do not have a past, nor a future.

The findings of the minimal group studies were surprising because they conflicted with the main perspective on inter-group relations by the time: Realistic Conflict Theory (Sherif \& Sherif, 1969). According to that perspective, real conflict over scarce material resources (money, housing, food) was necessary for inter-group conflict to arise. Although the participants in the minimal group studies allocated more money to their own group than to the other group, there was no way in which the person him- or herself could directly profit from this. Later studies also showed that in-group bias in the minimal group paradigm emerges along more symbolic dimensions, for example, when rating the in-group and out-group on traits, or when rating artistic products made by in-group and out-group members (Scheepers, Spears, Doosje, \& Manstead, 2006). This all suggested that real conflict over material 
resources is not necessary for in-group favoritism to emerge. But what could then account for it?

\section{Box 3. Question for Elaboration: Your Money or Your Identity?}

Social identity theory and realistic conflict theory stress different primary factors underlying inter-group attitudes: Social identity stresses identity, whereas realistic conflict theory stresses material resources. Think for a moment about negative attitudes towards migrants. Which arguments related to identity or instrumental factors are typically put forward? Then think about the striding European integration. Which instrumental or identity factors play a role in attitudes towards the European Union?

\section{From Category to Identity}

To explain the results of the minimal group experiments, Tajfel proposed that the persons had categorized themselves as a member of the minimal category they had been assigned to, the Klee or Kandinsky group. That is, the group had become part of the person's identity. But how could this explain in-group favoritism? Tajfel argued that people strive for a positive social identity, just as they strive for a positive personal identity (the part of identity that makes you a relatively "unique" individual). In the absence of further information about the value of the group, showing in-group favoritism was the only way in which people in the minimal inter-group situation could positively differentiate the in-group from the out-group. Thus, striving for positive group-distinctiveness, and thus a positive social identity, explains in-group favoritism in the minimal group paradigm.

The more general and basic psychological processes underlying social identity definition and striving for a positive social identity, which form the heart of SIT, are displayed in Figure 1. The theory starts with the notion that social categorization, i.e., dividing the social world into groups, is by definition self-relevant: You always belong to one of the two social categories, or a third (e.g., outsider) category. For example, when seeing two crowds of 
football fans this may make salient your identification with one of these teams, a third team, or even with the category of people "not interested in football". For each of these possibilities, the basic cognitive social categorization-process implies a part of your identity. This selfcategorization in combination with the motivation for a positive social identity elicits social comparison with relevant out-groups aimed at positively differentiating the in-group from these out-groups (Tajfel \& Turner, 1979).

\section{Box 4. Zooming in: Preventing Discrimination by Expanding "We".}

Social identity theory describes how identity motives can form the basis of in-group favoritism. Can the same identity principles also be applied for intervening inter-group conflict? The Common In-group Identity Model (Gaertner \& Dovidio, 2000) does indeed suggest they can. More specifically, the model shows that bias by members of one group (e.g., psychology students) towards members of another group (e.g., physics students) can be decreased by making a common identity salient (e.g., "Tubingen students"). Thus, by expanding the inclusiveness of the in-group by means of a higher level of social categorization, in-group bias can be decreased. Recent work has shown that creating a common in-group identity is particularly effective in reducing bias when it is combined with simultaneously stressing the ties with the subgroup and the overarching common identity (e.g., "Tubingen psychology students"). Such "dual identities" work particularly well because they secure subgroup distinctiveness, while at the same time they create common ground with the out-group (Dovidio, Gaertner, \& Saguy, 2007).

When successfully differentiating the in-group in a positive way from out-groups this contributes to a positive social identity. Such a positive sense of self does in turn serve basic human needs like the need for certainty and the need for self-esteem. Moreover, by partly 
defining the place of the individual in the social world, creating positive group distinctiveness also serves the search for meaning: It tells us who we are (and who we are not), where we belong, and how we should behave (Abrams \& Hogg, 1988; Scheepers et al., 2006).

\begin{tabular}{|l|l|l|l|}
\hline Process & \multicolumn{1}{|c|}{$\begin{array}{l}\text { Social } \\
\text { Categorization }\end{array}$} \\
\cline { 2 - 4 } & $\begin{array}{l}\text { Dividing the social world } \\
\text { in different categories of } \\
\text { people is always self- } \\
\text { relevant } \text { You always } \\
\text { belong to one of the } \\
\text { groups or a third (e.g., } \\
\text { outsider) group. This } \\
\text { lays the basis for social } \\
\text { identity. }\end{array}$ \\
\hline
\end{tabular}

Figure 1: Social Identity Definition

Thus, the basis of SIT is formed by cognitive processes (categorization, social comparison) in combination with the motivation to obtain a positive social identity. However, as illustrated with our opening examples, there are also important affective aspects to social identity. Indeed, more modern conceptualizations of social identity distinguish among different components of social identity, like cognitive components (self-categorization, or sefl-stereotyping), affective components (self-esteem, or satisfaction), and behavioral components (group commitment, or solidarity; Ellemers, Kortekaas, \& Ouwerkerk, 1999; Leach, Ellemers, \& Barreto, 2007; Ouwerkerk, Ellemers, \& De Gilder, 1999). These different components are also reflected in the different items and scales that are typically used to measure identification (See Table 1). 
Table 1. Different dimensions of social identification with typical items (from Leach et al., 2008)

\section{Dimension}

Example item

Solidarity

"I feel committed to [In-group]"

Satisfaction

I am glad to be [In-group]

Centrality

"I often think about the fact that I am [Ingroup]"

Individual Self-Stereotyping "I have a lot in common with the average [In-group] person"

In-group Homogeneity "[In-group] people have a lot in common with each other"

At this point you may wonder "what's then so social about social identity theory"? Indeed, these intra-personal cognitive processes and motives for certainty, esteem and meaning might seem more or less individualistic in nature. However, social identity theory is truly a social psychological theory, because, according to the theory, the social context (partly) determines which part of (social) identity is salient at a given moment. For example, your identity as member of a sports team is more likely to be salient during a close game 
against a rival team, while your personal identity is more likely to be salient when socializing with your team-mates after the game (Tajfel \& Turner, 1979). Thus, the social context is key to SIT in explaining which part of one's (social) identity becomes salient at a given moment. When a Social Identity is Negative

The social character of the theory is also echoed in the second part of social identity theory, the social-structural part. This part basically deals with the issue of how people respond to having a negative social identity.

One aspect in which minimal groups are minimal, is that they are neutral in terms of their valence. Natural groups, by contrast, do typically have evaluative connotations. That is, some groups are generally respected and enjoy a high social status (e.g., physicians) whereas other groups have low status, sometimes even to the extent that they can be regarded "stigmatized groups" (e.g., the unemployed). Because SIT predicts that people are generally motivated to achieve a positive social identity, members of low status groups should be motivated to improve the social standing of their group. By contrast, members of high status groups should be particularly motivated to protect the social standing of their group (Scheepers, 2009; Turner \& Brown, 1978).

For example, imagine that you are a player in a hockey-team that, for the third year in a row, finds itself up at the bottom of the league. How would you feel, and what would you do? The group's bad performance likely has a negative impact on the team members' social identity. How can they cope with this threat? Social identity theory describes three options. The first one, individual mobility, involves trying as an individual to seek entrance to a higher status group like another hockey team, or even club. The second option, collective action, involves working as a group for status improvement. Your team may engage in team-building activities to increase cohesion, or schedule more training sessions. As a result, the team may be able to do better and increase its status in the next season. The third option is to be 
"socially creative" and to change the comparison group ("although we ended at the bottom of the second league, we are definitively better than those in the third league") or the dimension of comparison ("although we are not brilliant at hockey, we are definitively the most fun team in the league, and hey, in the end, what is amateur sports all about?").

In addition to the distinction between the different ways to cope with a negative social identity, SIT also specifies the factors determining which strategy is likely to be used. Classic SIT describes three socio-structural variables that determine which coping response is chosen: The permeability of group differences (is moving to another group possible?), and the legitimacy and stability of the status differences (are the status differences fair, and is change possible?; Ellemers, 1993; Tajfel \& Turner, 1979).

When do people engage in collective action, and when do they engage in individual mobility? (See Figure 2). For individual mobility to be possible in the first place, the group must be permeable, which is the case for sport teams, but less so for social categories like gender and ethnicity. When boundaries are closed, the stability and legitimacy of the statusdifferences play an important role in whether one opts for collective action or social creativity. When status differences are illegitimate ("the referees have been consistently biased against our team") and unstable ("we attracted a couple of good young players") collective action will become more likely; when low status is legitimate and stable, however, social creativity becomes more likely ("we are the more fun team"). Thus, social identity threat is an important motivational principle determining, for example, whether one flees from the group individually, or fights the status quo as a group (Ellemers, 1993; Tajfel \& Turner, 1979).

This concludes our description of the basic principles of social identity theory. In the next sections we describe two important domains of application of the theory: health and organizations. 


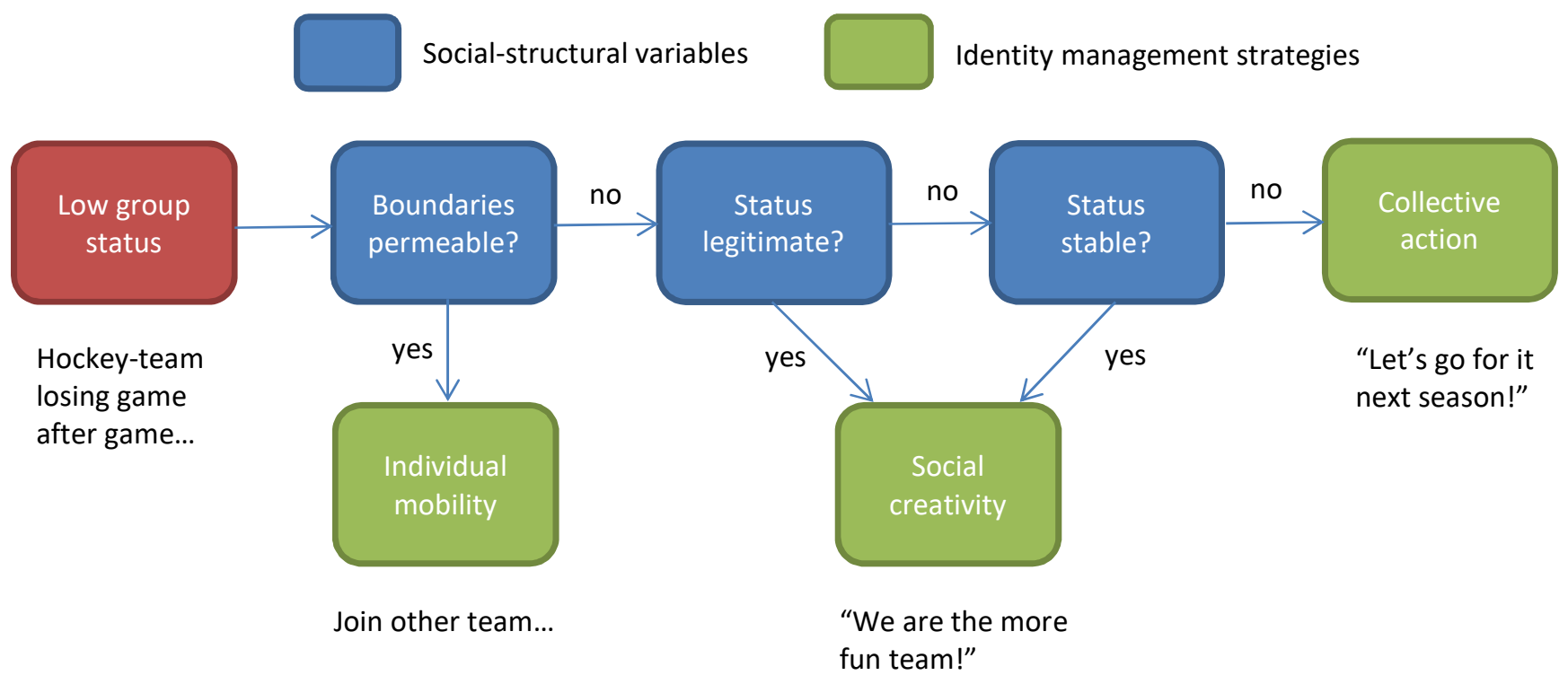

Figure 2: Social-structural variables and identity management strategies 


\section{Applications to Health}

Social identification has important implications for (improving) mental and physical health (Haslam, Jetten, Postmes, \& Haslam, 2009). In this section we briefly describe two ways in which social identity shapes heath-outcomes: The influence of group identification on health behavior and the influence of group identification on stress reduction.

Members of the lower social classes or ethnic minority-groups suffer from more negative health outcomes compared to members of the middle-class or ethnic majority-groups (e.g., Braveman, Egerter, \& Williams, 2011). Part of this relationship is explained by social identification. For example, research has indicated that members of racial minority-groups in the US were particularly likely to associate health-behaviors like exercising, eating healthy, and getting enough sleep, with the white middle-class. As a tragic consequence of this, after making their ethnic identity salient, ethnic minority-group members showed a greater "health fatalism", i.e., a believe that it will be of no use to engage in a more healthy lifestyle (Oyserman, Fryberg, \& Yoder, 2007).

Social identity can also be used to stimulate positive health behaviors, however. A study on anti-smoking advertisements demonstrated that their effectiveness partly depends on the extent to which a message is framed in terms of the target's social identity (Moran \& Sussman, 2014). Participants in this online questionnaire-study were adolescents, who first indicated on scales how much they identified with 11 possible peer-groups (e.g., "emo", "hiphop-er", "skater"). In turn they viewed an advert that displayed two anti-smoking beliefs (e.g., "Tobacco company executives have called younger adult smokers 'replacement smokers"'). A graphic designer had created 11 different versions of the adverts to fit each of the peer groups. Specifically, next to the statement two persons (an adolescent boy and girl) were displayed who had the prototypical features of a particular peer group (e.g., two typical skaters). Then, one week later the participants indicated their agreement with the two anti-smoking belief 
statements. Results indicated that a stronger identification with a certain peer group led to more endorsement with the statements. Thus, "customizing" a health message to fit a target's social identity increases the effectiveness of the message.

A second way in which social identification influences health-outcomes is through its stress-attenuating function. For example, Haslam and colleagues (2005) examined stress in Norwegian heart patients who were recovering from heart surgery in a clinic. Participants filled in a questionnaire measuring their identification with family and friends (e.g., "I identify with my family/friends"), received social support (e.g., "Do you feel you get the emotional support you need”?), and stress (e.g., “Are you stressed?”). Results indicated that identification with family and friends was inversely related to stress. Importantly, social identification was positively related to social support, and the negative relation between identification and stress was mediated by social support.

Identification may also have a positive effect on well-being when the group itself forms the basis of stress. According to the Rejection Identification Model (Branscombe, Schmitt, \& Harvey, 1999), group-based rejection initially threatens one's self-esteem, but through a strengthened identification with the group the person can in turn cope with the stress, eventually leading to restored self-esteem. In line with the model, Branscombe et al. showed that when Black Americans thought about discrimination against their racial group this initially led to depressed self-esteem. However, this social identity threat led in turn to a strengthened ethnic identification, which then led to higher self-esteem (see Schmitt, Branscombe, Kobrynowicz, \& Owen, 2002, for similar effects regarding gender groups).

Thus, the above research suggests that a social identity perspective is not only useful for making health campaigns more effective but also for designing interventions to reduce stress. An obvious context for applying these insights is the work context, where people may experience considerable amounts of stress. Indeed, the work by Haslam et al. (2005) suggests 
that by raising support and social identification, teams can become more resilient against stress. In addition to such interventions for work-stress, the social identity perspective has offered considerable insights in other themes in organizational psychology. These themes are discussed in the next section.

\section{Applications to Organizational Psychology}

Most people spend a large part of their time interacting with each other in groups, when they are at work in organizations. Accordingly, it has been argued that the insights offered by social identity theory can help understand the thoughts, feelings, and behaviors of individuals working in teams and organizations (e.g., Ashforth \& Mael, 1989; Haslam \& Ellemers, 2005; Haslam, Van Knippenberg, Platow, \& Ellemers, 2003; Hogg \& Terry, 2000). In this section, we demonstrate the added value of considering employees in terms of their group-based identities -instead of treating them as separate individuals- in addressing a number of problems faced by many work organizations.

\section{Box 5. Question for Elaboration: What do you identify with at work?}

When you think about finding an organization to work in as a professional after completing your studies, what would be most important criterion for you? Does this differ from what you seek in your current (side-)job? How happy are you with your employment conditions and with the way you are treated by your manager? Which is more important for your motivation to perform as best you can?

The added value of applying insights from Social Identity Theory has been demonstrated for a range of common challenges faced by organizations (see Table 2), for which we will give some examples below. These relate to: 
(a) cognitive categorization of the self as a member of the organization (How can leadership connect individual employees to work towards common goals? When will differentiation in employee rewards enhance individual ambitions or invite protest?); (b) evaluative judgments of the organization (Which organizational features are important to recruit and retain employees? Which help secure customer loyalty?); (c) emotional commitment to the organization (How to motivate workers to go the extra mile? How to create a sense of belonging when employees only communicate on-line?);

(d) identity change (How to accommodate minority employees? How to secure cooperation through an organizational merger?).

\section{Leaders can Define a Shared Identity}

Many companies use performance evaluations and incentives that compare workers against each other, for instance to determine who receives a bonus or qualifies for promotion. This is generally seen as a legitimate and effective system to motivate employees to work hard. However, the downside of such practices is that they foster competition between individuals and emphasize their personal identity, inviting people to think of themselves as individual workers, instead of as parts of a larger team or organization. If you work in a callcenter, for instance, where employee performance is rated by the speed at which you are able to take new calls, would you invest in providing the best possible service to each caller, so that they are satisfied and perhaps purchase additional services from the organization, or would you focus on completing each call as quickly as you can? 
Table 2. Organizational Topics, applications and implications of insights from Social Identity Theory

\begin{tabular}{|c|c|c|c|c|}
\hline $\begin{array}{l}\text { Organizational } \\
\text { Topic }\end{array}$ & $\begin{array}{l}\text { Identity } \\
\text { Relevance }\end{array}$ & Main Concern & $\begin{array}{l}\text { Behavioral } \\
\text { Implication }\end{array}$ & $\begin{array}{c}\text { Representative } \\
\text { Publication }\end{array}$ \\
\hline $\begin{array}{l}\text { Leadership in } \\
\text { Organizations }\end{array}$ & $\begin{array}{l}\text { Cognitive } \\
\text { Categorization }\end{array}$ & $\begin{array}{l}\text { Defining a } \\
\text { shared identity }\end{array}$ & $\begin{array}{l}\text { Common goal } \\
\text { pursuit }\end{array}$ & $\begin{array}{l}\text { Haslam, Reicher, \& } \\
\text { Platow, } 2011\end{array}$ \\
\hline $\begin{array}{l}\text { Organizational } \\
\text { Protest }\end{array}$ & $\begin{array}{l}\text { Cognitive } \\
\text { Categorization }\end{array}$ & $\begin{array}{l}\text { Dealing with } \\
\text { inequality }\end{array}$ & $\begin{array}{l}\text { Individual mobility } \\
\text { vs Collective action }\end{array}$ & $\begin{array}{l}\text { Veenstra \& } \\
\text { Haslam, } 2000\end{array}$ \\
\hline $\begin{array}{l}\text { Employee } \\
\text { Attraction }\end{array}$ & $\begin{array}{l}\text { Evaluative } \\
\text { Judgment }\end{array}$ & $\begin{array}{l}\text { Material vs } \\
\text { Identity benefits }\end{array}$ & $\begin{array}{l}\text { Recruitment and } \\
\text { retention }\end{array}$ & $\begin{array}{l}\text { Ashforth \& } \\
\text { Kreiner, } 1999\end{array}$ \\
\hline Customer Loyalty & $\begin{array}{l}\text { Evaluative } \\
\text { Judgment }\end{array}$ & $\begin{array}{l}\text { Being a valued } \\
\text { supplier }\end{array}$ & $\begin{array}{l}\text { External image } \\
\text { protection }\end{array}$ & $\begin{array}{l}\text { Malone \& Fiske, } \\
2013\end{array}$ \\
\hline $\begin{array}{l}\text { Motivation and } \\
\text { Performance }\end{array}$ & $\begin{array}{l}\text { Emotional } \\
\text { commitment }\end{array}$ & $\begin{array}{l}\text { Individual vs } \\
\text { Team incentives }\end{array}$ & $\begin{array}{l}\text { Exploiting the } \\
\text { organization vs } \\
\text { Going the extra mile }\end{array}$ & $\begin{array}{l}\text { Ellemers, Van den } \\
\text { Heuvel, \& De } \\
\text { Gilder, } 1998\end{array}$ \\
\hline $\begin{array}{l}\text { Communication } \\
\text { and Decision } \\
\text { making }\end{array}$ & $\begin{array}{l}\text { Emotional } \\
\text { commitment }\end{array}$ & $\begin{array}{l}\text { (virtual) Team } \\
\text { building }\end{array}$ & $\begin{array}{l}\text { Displays of (over-) } \\
\text { commitment, group } \\
\text { think }\end{array}$ & $\begin{array}{l}\text { Postmes, Tanis, \& } \\
\text { De Wit, } 2001\end{array}$ \\
\hline $\begin{array}{l}\text { Diversity and } \\
\text { Inclusion }\end{array}$ & Identity change & $\begin{array}{l}\text { Dealing with a } \\
\text { negative identity }\end{array}$ & $\begin{array}{l}\text { Discrimination and } \\
\text { exclusion }\end{array}$ & $\begin{array}{l}\text { Danaher \& } \\
\text { Branscombe, } 2010\end{array}$ \\
\hline $\begin{array}{l}\text { Organizational } \\
\text { Mergers }\end{array}$ & Identity change & $\begin{array}{l}\text { Lack of respect } \\
\text { and belonging }\end{array}$ & $\begin{array}{l}\text { Competition and } \\
\text { compliance failure }\end{array}$ & $\begin{array}{l}\text { Terry, Carey, \& } \\
\text { Callan, } 2001\end{array}$ \\
\hline
\end{tabular}

An important challenge for leadership in cases such as this is to help individual employees build and retain a sense of identification with the team or organization. This can enhance their willingness to work towards shared goals - such as maintaining long-term relations with satisfied customers (Ellemers, De Gilder, \& Haslam, 2004). Indeed, employees are more inclined to follow the guidance of leaders as these more clearly support the preferences of their own team members (e.g., making sure they have enough information to provide satisfactory answers to questions they receive) and protect them against claims of other teams or organizational members (e.g., that the people at the call-center work too 
slowly). Leaders who are able to do this well allow workers to self-categorize at the group level instead of the individual level (Haslam \& Platow, 2001).

This also implies that those with formal positions of power are not necessarily the ones who are most influential in guiding the organization and its members. The possibility they have to decide about business strategies, enforce requests, or afford resources gives them control over the outcomes of employees. However, it is the ability of leaders to connect, engage, and inspire others that causes employees to follow their guidance. More often than not, this is enhanced by their willingness to acknowledge and transform important concerns of individual employees (e.g., their frustration of having to mind the time when answering customer requests) and to define how shared team or organizational goals contribute to fulfilling the goals and ambitions of individual workers (see also Haslam, Reicher, \& Platow, 2011).

\section{Box 6. Zooming in: The Costs of Competing Against Each Other}

Organizations where workers are encouraged to compete with each other for customers and resources hope to optimize the profits and efficiency of the company in this way (Victor \& Cullen, 1988). Studies with many different professional groups and companies across the world have revealed the drawbacks of this motivational strategy, which is typically associated with reduced work satisfaction and organizational commitment among workers. Further, rewarding workers for the individual performance they show, without taking into account how they achieved this performance, has been found to elicit a range of unethical work behaviors. These include lying, stealing, misreporting results, falsifying reports, accepting bribes, and bullying in the company (Martin \& Cullen, 2006; Simha \& Cullen, 2012). 


\section{What Makes for an Attractive Workplace?}

Unfortunately, many organizations have a limited view on what determines the value people attach to their place of work. Human resources and recruiting officers tend to emphasize material gains, such as personal career opportunities, compensation packages, or other employee benefits when recruiting new employees. However, different studies have found that these are not the only things that matter. Instead, the main thing people want to know before they apply for a job is whether this can make them proud of their organizational identity. Organizations with high prestige reflect positively on the self-conceptions of employees and enhance their identification with the organization (Smidts, Pruyn, \& van Riel, 2001).

Organizational prestige and feelings of pride in belonging to the organization do not necessarily depend on its financial successes or business reputation. Instead, those who consider working for the organization mainly have an interest in knowing whether the organization supports important values. For instance, it has been established that workers are more satisfied and committed to the organization when they perceive organizational management to be truthful in communicating with employees and stakeholders, and to engage in socially responsible business practices (Van Prooijen \& Ellemers, 2015; Ellemers, Kingma, Van der Burgt \& Barreto, 2011). As a result, even individuals who work in sectors that are often seen as having low prestige (such as garbage collectors, undertakers, or sex workers), can take pride in their profession and identify with the organization that employs them, by focusing on important societal functions they fulfill, for instance by averting public health threats, or offering emotional support to lonely people (Ashforth \& Kreiner, 1999). 


\section{Box 7. Definition Box: Organizational identification and commitment}

Although the term 'organizational identification' is often used in the management literature, this is often defined and measured differently than in social identity theory. Importantly, management studies often separate cognitive self-categorization (which they consider to capture the 'organizational identity' of employees) from emotional involvement with the organization (which they indicate as 'organizational commitment'), and conclude that identity is less relevant than commitment to predict behavior in organizations. This is different from the notion of the 'group-based-self' in social identity theory, which incorporates selfcategorization as well as commitment as essential components of a social identity.

\section{Going the Extra Mile}

The importance of a common social identity for motivation and performance at work has been demonstrated in many studies. Again, selfish concerns, such as the fact that workers depend on each other to achieve valued outcomes appear less important than a sense of emotional involvement and subjective feelings of commitment to one's team and the organization. This was observed for instance among Dutch soldiers on a UN peacekeeping mission. Here it was found that the more soldiers in military teams felt that they were respected and included, the more likely it was that their commanders considered the team ready for combat (Ellemers, Sleebos, Stam, \& De Gilder, 2013). The power of noninstrumental factors in connecting and motivating people at work is further demonstrated in studies among volunteers. Their sense of identification and commitment to the volunteer organization and its mission motivates them to work even without pay (e.g., Boezeman \& Ellemers, 2008). This also means that it can be very costly for organizations to prevent employees from developing such a sense of emotional involvement, for instance by failing to 
acknowledge and include them as valued members of the organization. This can happen in sectors where it is common practice to offer flexible, parttime, or limited duration work contracts only (see also Ho, 2009). Even if this may seem a good way to optimize employment efficiency, such organizations cannot expect workers to develop a sense of common identity, or to 'go the extra mile' to achieve outcomes that are important for the organization. Surely you would not be willing to work overtime to meet a deadline, or help instruct new co-workers, after having been told your contract is not extended because someone with your level of experience is considered 'too expensive' to retain.

\section{Box 8. Zooming in: The dangers of overcommitment}

In itself, a strong team or organizational identity is no guarantee for an optimal performance at work (see also Ellemers, De Gilder, \& Haslam, 2004). In fact, a strong shared identity may tempt workers to cover up each other's mistakes, or encourage each other to take it easy. At the other end of the spectrum, people who overcommit to their work identity may be quite productive for a while but are unlikely to be able to keep this up indefinitely. In the long run, the social and personal sacrifices people make when they focus on their work identity alone can prevent them from investing in other important identities, for instance relating to family, friends, sports, or cultural activities (Faniko, Ellemers, Derks, \& Lorenzi-Cioldi, 2017).

\section{Managing Diversity}

Even in organizations that are aware of the importance of connecting people and encouraging them to develop a shared identity, there may be additional difficulties to overcome. An important challenge in this sense is offered by changing workplace realities, which are characterized by increasing diversity among workers. Being able to recruit the inputs from people with different cultural backgrounds, types of training, or life experiences can be a valuable asset to many companies. However, if not managed well, such differences 
in the type of knowledge and experience people bring to work as well as more immediately visible differences in their gender or skin color can easily become a source of misunderstanding and divisiveness. These features that separate workers or cut across common team or organizational memberships can induce (implicit) discrimination, and make those who differ from the majority feel excluded. The challenge for leadership is to make sure that such alternative identities are acknowledged and recruited into a common overarching identity. This can be achieved for instance by clarifying how such differences can form a resource for greater flexibility and creativity (e.g., "we need workers who know how to digitalize our services"), or allow the organization to connect to a broader population of clients (e.g., "we need workers who know how to communicate with non-native speakers"; Ellemers \& Rink, 2016). Thus, attempts to build a common organizational identity should not ignore such differences. Instead identity building initiatives do well to emphasize and enhance the different types of contribution workers can make to the organization and what it stands for, instead of letting such differences become a source of disagreement and conflict.

In sum, there is considerable evidence that social identities are important in organizational contexts. At the same time, strengthening a common identity for instance through 'team building' activities is no easy or foolproof solution to make workers feel connected and perform well. To be able to build and benefit from the willingness of individuals to identify with their place of work, organizational leaders do well to reconsider standard business practices that can undermine shared goals and common identities. Making people feel respected and included as valued organizational members - regardless of their differences, making sure that organization and its activities can make workers proud, and taking care not to be too greedy in requesting that workers sacrifice other identities to fit in, all are important challenges that need to be met to be able to connect workers into a happy, healthy and productive organization. 


\section{Intervening to Improve Inter-group Contact and Collaboration}

An important theme within social identity research is how SIT principles can be used to improve inter-group relations in a variety of contexts. One of the most influential ideas in this context is that creating a common in-group identity that comprises both in-group and outgroup reduces bias towards (former) out-group members (Dovidio et al., 2007; Gaertner \& Dovidio, 2000; see Box 5). For example, this idea has been used to understand corporate mergers, where a common challenge is often to unify companies that were previously competing against each other, and might have different identities, cultures, and statuses. Understanding the social identity dynamics of such mergers is key for making the merger a success (Terry, Carey, \& Callan, 2001). Another context where SIT principles have been used to stimulate inter-group helping and cooperation is the educational context. We conclude this chapter by describing a social identity intervention to improve inter-group relations at schools and universities.

One challenge that many schools and universities currently face is the increasing diversity in their student populations. This diversity can take different forms, for example increasing numbers of students with an migration background, or increasing gender diversity in areas that were traditionally male-dominated (e.g., math). How can you stimulate a positive school climate and collaboration in such contexts?

Vezzali et al. (2015) tested a common in-group identity intervention in two educational settings: an elementary school setting (Study 1) and a university setting (Study 2). Participants in the first study were native-Italian elementary school-children. Within different classes participants were randomly assigned to one of three conditions. In the "common ingroup condition" participants imagined working together with an immigrant child on a competitive task against another dyad. This condition was compared to two (control) 
conditions: In the "imagined contact condition" participants had to simply imagine contact with an immigrant child, without working together; In the "control condition" the instructions were as in the common in-group identity condition but the migration-background of the interaction partner was not mentioned. Participants engaged in the imagining task once a week over a four-week period. The context that participants had to imagine differed from week to week (e.g., sports, theater play). Each time, participants were instructed to close their eyes and take a third-person perspective while imagining the situation. One week after the final intervention task inter-group helping intentions were measured using a questionnaire (e.g., "Think about an immigrant child who may have problems with writing an essay. Would you help him/her?") Then, again one week after this assessment the experimenter met individually with each of the participants and further interviewed him/her about helping intentions. More specifically, the participant was informed that a new pupil with an immigrant background would arrive soon at their school, and the participant was asked whether (s)he would be willing to help the new child with integrating at school. Participants were asked about the number of afternoons (between 0 and 4) they would be willing to help-out their new classmate.

Results on both helping measures indicated that participants in the common in-group identity condition were more likely to help an immigrant classmate than participants in the control condition. Helping intentions in the imagined contact condition fell in between the common in-group condition and the control condition.

These results were replicated in a second study in an university context. This study used basically the same set-up as the school study but also comprised a questionnaire measuring common in-group identity (e.g., "Do you perceive Italians and immigrants as members of a common group [residents of Italy]?"). Results indicated, as would be expected, that the common in-group identity measure indeed mediated the positive effects of the 
common in-group identity intervention on the willingness to engage in future inter-group contact.

Together these two studies illustrate the fruitfulness of a common identity intervention to improve inter-group contact and cooperation in an educational setting. It should be noted that although the intervention itself was relatively simple to implement, its effects were sustainable in that it predicted out-group helping two weeks later.

\section{Summary}

Human beings are advanced social animals: People not only form groups; groups also form people. People derive part of their identity from the groups to which they belong, which is called their "social identity". Social identity theory describes how-through social categorization and comparison-people define their social identity, and how they strive for a positive social identity. The need for a positive and meaningful social identity is served by positive group distinctiveness which contributes to feelings of certainty and positive selfesteem.

A negative social identity, for example stemming from membership in a group with a relatively low status, is threatening. People cope with a negative social identity in various ways, like trying to improve the status of the group or seeking entrance in a higher status group.

Social identity has important implications for health psychology, for example, for customizing health interventions. Moreover, group identification can buffer against stress and positively contribute to well-being. Social identity has also important implications for how people behave, feel, and cooperate in organizational contexts. For example, social identity plays a key role in motivation, leadership effectiveness, and managing diversity. The creation 
of a common in-group identity comprising the in-group and a (former) out-group is a widely applied intervention to improve inter-group relations in a variety of settings.

\section{Recommended Reading}

Ellemers, N., \& Haslam, S.A. (2012). Social identity theory. In: P. van Lange, A. Kruglanski, \& T. Higgins (Eds.), Handbook of theories of social psychology (pp. 379-398). London: Sage.

Haslam, A., Van Knippenberg, D., Platow, M., \& Ellemers, N. (Eds.) (2003). Social identity at work: Developing theory for organizational practice. Psychology Press.

Jetten, J., Haslam, C., \& Haslam, S. A. (Eds.) (2012). The social cure: Identity, health and well-being. New York: Psychology Press. 


\section{Guiding Answers to Questions in the Chapter}

\section{Box 3. Question for Elaboration: Your Money or Your Identity?}

Migrants can be seen as threat to the material resources of the host society, like housing, health-care, and the sustainability of social security programs. By bringing their cultural habits and religion, migrants are often also seen as a threat to the identity and culture of the host society. The European integration can be seen as a threat to the material resources of the inhabitants of certain rich countries, when they feel having to compensate countries with less well-functioning economies. Moreover, by seemingly blending the unique cultural features of member states the European union is also often seen as a threat to national identities.

\section{Box 5. Question for Elaboration: What do you identify with at work?}

People can focus on different aspects of their work as providing them with a source of identification and commitment. Many academics, for instance, primarily identify with their academic discipline or profession (being a physicist, being a historian), and may attach less value to the university or academic institution that employs them. Workers in large corporations may identify with their career development goals (being a management trainee), with their work team (IT department), or with the organization (K-Mart). What people adopt as the primary focus for their professional identity, is guided also by the way the organization treats them, the development opportunities and career prospects they receive. For instance, an organization that only offers flexible or temporary contracts will have more difficulty having its workers develop a sense of identification with the organization. Likewise, leadership communications and incentives programs can lead workers to categorize themselves differently, for instance as part of a group of experts, work team, or organization. 


\section{References}

Abrams, D., \& Hogg, M. A. (1988). Comments on the motivational status of self-esteem in social identity and intergroup discrimination. European Journal of Social Psychology, $18,317-334$.

Ashforth, B. E., \& Kreiner, G. E. (1999). “How can you do it?”: Dirty work and the challenge of constructing a positive identity. Academy of Management Review, 24, 413-434.

Ashforth, B. E., \& Mael, F. (1989). Social identity theory and the organization. Academy of Management Review, 17, 20-39.

Boezeman, E., \& Ellemers, N. (2008). Volunteer recruitment: The role of organizational support and anticipated respect in non-volunteers' attraction to charitable volunteer organizations. Journal of Applied Psychology, 93, 1013-1026.

Branscombe, N. R., Schmitt, M. T., \& Harvey, R. D. (1999). Perceiving pervasive discrimination among African-Americans: Implications for group identification and well-being. Journal of Personality and Social Psychology, 77, 135-149.

Braveman, P., Egerter, S., \& Williams, D. R. (2011). The social determinants of health: Coming of age. Annual Review of Public Health, 32, 381-398.

Danaher, K., \& Branscombe, N. R. (2010). Maintaining the system with tokenism: Bolstering individual mobility beliefs and identification with a discriminatory organization. British Journal of Social Psychology, 49, 343-362.

Dovidio, J. F., Gaertner, S. L., \& Saguy, T. (2007). Another view of "we”: Majority and minority group perspectives on a common ingroup identity. European Review of Social Psychology, 18, 296-330.

Ellemers, N. (1993). The influence of socio-structural variables on identity management strategies. In W. Stroebe \& M. Hewstone (Eds.), European Review of Social Psychology, 4, 27-57. 
Ellemers, N., De Gilder, D., \& Haslam, S. A. (2004). Motivating individuals and groups at work: A social identity perspective on leadership and group performance. Academy of Management Review, 29, 459-478.

Ellemers, N., De Gilder, D., \& Van den Heuvel, H. (1998). Career-oriented versus team-oriented commitment and behavior at work. Journal of Applied Psychology, 83, 717-730.

Ellemers, N., Kingma, L., Van de Burgt, J., \& Barreto, M. (2011). Corporate social responsibility as a source of organizational morality, employee commitment and satisfaction. Journal of Organizational Moral Psychology, 1, 97-124.

Ellemers, N., Kortekaas, P., \& Ouwerkerk, J. (1999). Self-categorization, commitment to the group and social self-esteem as related but distinct aspects of social identity. European Journal of Social Psychology, 29, 371-389.

Ellemers, N., \& Rink, F. (2016). Diversity in work groups. Current Opinion in Psychology, $11,49-53$.

Ellemers, N., Sleebos, E., Stam, D., \& de Gilder, D. (2013). Feeling included and valued: How perceived respect affects positive team identity and willingness to invest in the team. British Journal of Management, 24, 21-37.

Faniko, K., Ellemers, N., Derks, B., \& Lorenzi-Cioldi, F. (2017). Nothing changes, really: Why women who break through the glass ceiling end up reinforcing it. Personality and Social Psychology Bulletin, 43, 638-651.

Gaertner, S. L., \& Dovidio, J. F. (2000). Reducing intergroup bias: The common ingroup identity model. Philadelphia, PA: Psychology Press.

Haslam S. A., \& Ellemers, N. (2005). Social identity in industrial and organisational psychology. International Review of Industrial and Organizational Psychology, 20, 39-118. 
Haslam, S. A., O'Brien, A., Jetten, J., Vormedal, K., \& Penna, S. (2005). Taking the strain: Social identity, social support and the experience of stress. British Journal of Social Psychology, 44, 355-370.

Haslam, S., A., \& Platow, M. J. (2001). The link between leadership and followership: How affirming social identity translates vision into action. Personality and Social Psychology Bulletin, 27, 1469-1479.

Haslam, S., A., Reicher, S. D., \& Platow, M. J. (2011). The new psychology of leadership. London: Psychology Press.

Haslam, A., Van Knippenberg, D., Platow, M., \& Ellemers, N. (Eds.) (2003). Social identity at work: Developing theory for organizational practice. Psychology Press.

Ho, K. (2009). Liquidated: An ethnography of Wall Street. Durham: Duke University Press.

Hogg, M. A., \& Abrams, D. (1990). Social motivation, self-esteem and social identity. In: D. Abrams and M. A. Hogg (Eds). Social identity theory: Constructive and critical advances (28-47). London: Harvester Wheatsheaf.

Hogg, M. A., \& Terry, D. J. (2000). Social identity and self-categorization processes in organizational contexts. Academy of Management Review, 25, 121-140.

Leach, C., Ellemers, N., \& Barreto, M. (2007). Group virtue: The importance of morality vs. competence and sociability in the evaluation of in-groups. Journal of Personality and Social Psychology, 93, 234-249.

Leach, C. W., van Zomeren, M., Zebel, S., Vliek, M. L. W., Pennekamp, S. F., Doosje, B., Ouwerkerk, J. W., \& Spears, R. (2008). Group-level self-definition and selfinvestment: A hierarchical (multicomponent) model of in-group identification. Journal of Personality and Social Psychology, 95, 144-165.

Malone, C., \& Fiske, S.T. (2013). The human brand. San Francisco: Jossey-Bass. 
Martin, K. D., \& Cullen, J. B. (2006). Continuities and extensions of ethical climate theory: A meta-analytic review. Journal of Business Ethics, 69, 175-194.

Moran, M., B., \& Sussman, S. (2014). Translating the link between social identity and health behavior into effective health communication strategies: An experimental application using antismoking advertisements. Health Communication, 29, 1057-1066.

Ouwerkerk, J., Ellemers, N., \& De Gilder, D. (1999). Group commitment and individual effort in experimental and organizational contexts. In: N. Ellemers, R. Spears, \& B. Doosje (Eds.). Social identity: Context, commitment, content (184-204). Oxford: Basil Blackwell.

Oyserman, D., Fryberg, S. A., \& Yoder, N. (2007). Identity-based motivation and health. Journal of Personality and Social Psychology, 93, 1011-1027.

Postmes, T., Tanis, M, \& De Wit, B. (2001). Communication and commitment in organizations: A social identity approach. Group Processes and Intergroup Relations, 4, 227-246.

Scheepers, D. (2009). Turning social identity threat into challenge: Status stability and cardiovascular reactivity during intergroup competition. Journal of Experimental Social Psychology, 45, 228-233.

Scheepers, D., Spears, R, Doosje, B., Manstead, A. S. R. (2006). The social functions of ingroup bias: Creating, confirming or changing social reality. European Review of Social Psychology, 17, 359-396.

Schmitt, M. T., Branscombe, N. R., Kobrynowicz, D., \& Owen, S. (2002). Perceiving discrimination against one's gender group has different implications for well-being in women and men. Personality and social Psychology Bulletin, 28, 197-210.

Sherif, M., \& Sherif, C. W. (1969). Social Psychology. New York: Harper \& Row. 
Simha, A., \& Cullen, J.B. (2012). Ethical climates and their effects on organizational outcomes: Implications from the past and prophecies for the future. Academy of Management Perspectives, 26, 20-34.

Smidts, A., Pruyn, A. T. H., \& van Riel, C. B. (2001). The impact of employee communication and perceived external prestige on organizational identification. Academy of Management Journal, 44(5), 1051-1062.

Tajfel, H. (1970) Experiments in intergroup discrimination. Scientific American, 223, 96102.

Tajfel, H. (1978). Social categorization, social identity and social comparisons. In H. Tajfel (Ed.), Differentiation between social groups (pp. 61-76). London: Academic Press. Tajfel, H., \& Turner, J. C. (1979). An integrative theory of intergroup conflict. In W. G. Austin \& S. Worchel (Eds.), The social psychology of intergroup relations (pp. 3347). Monterey, CA: Brooks/Cole.

Terry, D. J., Carey, C. J., \& Callan, V. J. (2001). Employee adjustment to an organizational merger: An intergroup perspective. Personality and Social Psychology Bulletin, 27, 267-280.

Turner, J. C., \& Brown, R. (1978). Social status, cognitive alternatives, and intergroup relations. In H. Tajfel (Ed.), Differentiation between social groups (pp. 201-234). London: Academic Press.

Van Prooijen, A. M., \& Ellemers, N. (2015). Does it pay to be moral? How indicators or morality and competence enhance organizational and work team attractiveness. British Journal of Management, 26, 225-236.

Veenstra, K., \& Haslam, S. A. (2000). Willingness to participate in industrial protest: Exploring social identification in context. British Journal of Social Psychology, 39(2), 153-172. 
Vezzali, L., Stathi, S., Crisp, R. J., Giovannini, D., Capozza, D., \& Gaertner, S. L. (2015). Imagined intergroup contact and common ingroup identity: An integrative approach. Social Psychology, 46, 265-276.

Victor, V., \& Cullen, J. B. (1988). The organizational bases of ethical work climates. Administrative Science Quarterly, 33, 101-125. 